\title{
Bank Competition and Credit Access: The Case of Informal Firms in Sub-Saharan Africa
}

\author{
Busani Moyo \\ https://orcid.org/0000-0002-5194-2343 \\ University of South Africa \\ moyob@unisa.ac.za
}

\author{
Athenia Bongani Sibindi \\ https://orcid.org/0000-0003-0953-8424 \\ University of South Africa \\ sibinab@unisa.ac.za
}

\section{Abstract}

Purpose of the study: This paper investigates the impact of bank competition on access to finance by informal firms in 14 sub-Saharan African countries, using World Bank enterprise survey data. Access to finance is one of the main factors identified as hindering the growth of opaque borrowers, who are generally characterised by poor financial transparency.

Methodology: This study uses a discrete binary choice probit model to estimate the probability or likelihood of accessing finance, conditional on the level of bank competition and other firm-level characteristics.

Findings: Results show that the impact depends on the competition measure used. The Lerner index shows a positive relationship supporting the information-based hypothesis, while the most robust competition indicator, the Boone index, is negative in line with the market power hypothesis. These results also show that reducing or minimising information asymmetry using public credit registries is good for enhancing financial access.

Research implications: Improving the competitiveness of the banking sector by encouraging the entrance of more players should be promoted without compromising the soundness of the sector. Measures should be introduced to control anti-competitive behaviour in the banking industry.

Originality: The informal sector contributes close to $50 \%$ to Africa's GDP and $80 \%$ towards employment and, therefore, strategies aimed at eliminating the obstacles faced by these firms are important for livelihood protection. Many studies done on the African banking industry have generally found it to be less competitive and this affects financial access since banks tend to be risk averse in such settings. There are also few studies that have analysed the relationship between bank competition and credit access in the informal sector, mostly because publicly available data on these firms are scarce.

Keywords: competition; credit access; informal firms, sub-Saharan Africa (SSA)

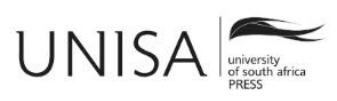




\section{Moyo, Sibindi}

\section{Introduction}

\section{Background}

The informal sector contributes significantly to the economies of developing countries by fostering economic growth, creating employment and alleviating poverty. Estimates of the size of the informal economy in sub-Saharan Africa (SSA), computed by Medina, Jonelis, and Cangul (2017) using the Multiple Indicator-Multiple Cause model (MIMIC) and the Predictive Mean Matching method (PMM), show that informality ranges from as low as 20-25\% in Mauritius, South Africa and Namibia to a high of 50$65 \%$ in Benin, Tanzania and Nigeria - suggesting that informality in SSA remains amongst the largest in the world, though gradually declining. The International Labour Organisation (ILO) 2018 report confirms this pattern by stating that two billion of the world's population above 15 years (representing $61.2 \%$ of global employment) eke out a living informally. However, in Africa, the African Development Bank (2013) estimates the informal sector's contribution to the continent's GDP and labour force at around 55\% and $80 \%$ respectively, making the sector the main driver of growth and source of livelihood. Informal employment, as a percentage of non-agricultural employment between the period 2004-2010, was estimated at 66\% for SSA compared to $51 \%$ in Latin America and $10 \%$ in Eastern Europe and Central Asia (Women in Informal Employment: Globalisation and Organising [WIEGO] 2012).

Informal employment is generally the main source of livelihood for women in the developing world (ILO, 2018). ILO statistics show that about $60 \%$ or more of women workers in the developing world are in informal employment outside agriculture. In SSA, 74\% of women non-agricultural workers are informally employed compared to $61 \%$ of male non-agricultural workers. In Latin America, the situation is also the same, with $54 \%$ of women informally employed compared to $48 \%$ of men. There is also a widespread belief that the informal sector is a social safety net for the poor and a training ground for budding entrepreneurs, and hence a trampoline to formality (World Bank 2011). Therefore, governments in developing countries, including Africa, are increasingly taking a keen interest in understanding what drives the performance of the sector, to come up with policy interventions that will bolster its growth. Understanding the challenges that these firms face is very important for their growth and the livelihood of people is dependent on it. Notwithstanding, the major impediment towards the growth of this sector lies in its ability to access finance from banks and other financial institutions. Providing finance may enable them to invest and improve their productivity, which in turn would foster economic growth and employment creation (Leon 2014).

World Bank enterprise surveys data show that firms in the informal sector identify lack of access to finance as the biggest obstacle to doing business. Informal firms in Angola, Burkina Faso, Cabo Verde and Mauritius have been unable to access loans from banks (World Bank 2020) and the main reason highlighted by these firms is that application 


\section{Moyo, Sibindi}

steps are too complicated. Therefore, finding ways of encouraging banks to develop access-friendly products that speak to the needs of informal players is important.

Prata and Quintin (2006) argue that it is difficult to enter into enforceable, verifiable business arrangements with an economic unit that does not exist legally, does not maintain credible accounting practices and often lacks a clear title to the assets it owns. Claiming collateral in the event of default is therefore difficult, if not impossible. However, since these are owner-managed businesses, it should be possible for the owners to cede their personal assets as collateral when borrowing from banks. In some cases, these owners have formal jobs and their employment earnings should reduce their risk of default. ${ }^{1}$ Competition and credit availability matter most for small and medium sized firms because these firms are more vulnerable to information problems and are much more bank dependent than large enterprises (Carbo-Valverde, RodriguezFernandez, and Udell 2008). Our contention is, bank competition can still improve financial access to these opaque firms by pushing them to develop innovative and viable products that consider their risk profiles. The fact that some banks can lend to these opaque firms means this market is lendable if appropriate lending methods are developed (World Bank 2020). Vives (2001) also argues that the contribution of competition to allocative, productive, and dynamic efficiency in banking is no different than in any other industry. The pressure of competition allows for innovation and the expansion of services, which should increase the availability of finance to more firms. Competition also pushes banks toward riskier borrowers, again expanding access to a wider variety of firms. More competition increases the supply of financial products, reduces the rates and fees paid, expands the number of financial providers and the network of bank branches, and increases the quality and variety of products offered (Vives 2001), with a positive effect on financial inclusion.

Although many African countries have implemented financial sector reforms, they are severely disadvantaged in financial development (Beck, Demirguc-Kunt, and Maksimovic 2009). The degree and the impact of competitiveness in the banking sector are of great importance as this has a great impact on the financial system and the wider economy (Banya and Biekpe 2017). Competition in the banking sector affects the efficiency, quality and degree of innovation of financial services and is often cited as an important driver of access to credit (Claessens and Laeven 2004; Leon 2014). Studies on bank competition done in SSA show that the sector is not competitive and varies between being a monopoly, as in Tunisia, to being monopolistic as in Zambia, South Africa and Ghana (Abdelkader and Mansouri 2013, Fosu 2013; Mengistu and PerezSaiz 2018; Moyo, 2018).

To understand the impact of bank competition, firm-level characteristics and information asymmetry on access to credit, we estimated a discrete binary choice model. We measured competition using the Boone and Lerner index and document several

1 About $43 \%$ of people running informal sector businesses are formally employed (World Bank, 2020). 


\section{Moyo, Sibindi}

findings. Firstly, the results lend credence to the market power hypothesis by establishing that if the level of competition in the banking sector is high (as proxied by the Boone indicator) the higher is the probability of informal firms getting financial access. Secondly, the results show that using the Lerner index there is a positive relationship with the probability of getting a loan supporting the information-based hypothesis.

This article is organised as follows. The next section covers the literature review. We explore the research gap and contribution of this study. The article then presents a profile of firms in study countries. The study's methodology, analysis and discussion of the results are covered. The article concludes with a discussion of policy implications regarding bank competition and credit access for informal firms in SSA.

\section{Literature Review}

\section{Research Gap and Contribution of the Study}

In recent decades, bank competition across countries has significantly changed after the gradual process of deregulation and significant reforms over the last three decades, following a long period of poor performance (Banya and Biekpe 2017; Vives 2001). The intention of deregulation was to enhance competitiveness and intermediary efficiency, also creating an environment conducive for increased foreign bank penetration (Moyo et al. 2014). However, it appears that financial liberalisation measures implemented in Africa have not changed the competitive landscape in the banking sector. Gaertna and Sanya (2012) provide available evidence for the East African Community and show that competition in the four countries studied was low. In Ghana, Biekpe (2011) found the banking sector to be non-competitive and monopolistic; something that he argues hampers financial intermediation. Similar results were found by Simpasa (2013) in Zambia, and Moyo (2018) in South Africa. However, Hauner and Peiris (2008) found contrasting evidence for Uganda, arguing that the level of competition has increased and so has bank efficiency. In Tunisia, Abdelkader and Mansouri (2013) found the banking sector to be a monopoly and thus very uncompetitive. Cross-country evidence also shows similar findings, with Mengistu and Perez-Saiz (2018) using the Global Financial Development database (2016-2019), which found that the Panzar Rosse H-statistic and Lerner indices indicate low bank competition levels among the SSA countries. Fosu (2013) and Kouki and Al-Nasser (2014) also found similar results, using a sample of SSA countries.

Given that most of the studies on bank competition in SSA generally converge on the sector being non-competitive, the question that we want to answer is: How has this affected informal firms' access to credit? This is because theories that explain the relationship between competition and access to finance predict different effects. The market power hypothesis argues that competition pushes banks to be innovative and thus expand the scope of their services, even towards riskier borrowers, thus improving credit availability to a variety of firms (Love and Peria 2014). On the other hand, the 


\section{Moyo, Sibindi}

information hypothesis predicts that low competition increases access to credit, particularly for opaque firms. This argument is supported by Petersen and Rajan (1995) who also theoretically show that banks wielding market power tend to lend to young firms whose credit records may be opaque, hence leading to high lending rates.

Our study seeks to use empirical informal sector data to answer the question raised above and to ascertain which hypothesis applies to informal firms in Africa. This study is related to three major studies done in this area by Love and Peria (2014), Ayalew and Xianzhi (2019) and Leon (2014). All these studies looked at the relationship between bank competition and access to finance, generally finding that low competition reduces firms' access to finance. Although we are using the data collected by the World Bank through investment climate surveys, our point of departure is that we will focus specifically on informal firms. The above studies only looked at formal firms in different countries across the world, including Africa. Love and Peria (2014) used formal firms in 53 countries, 12 of which were from SSA, while Ayalew and Xianzhi only looked at formal firms in 27 SSA countries. Leon (2014) covered formal firms in 69 developing and emerging countries, of which 23 were from SSA. The World Bank, since 2005, has so far collected data on informal firms in 29 countries worldwide and in only 19 SSA countries. ${ }^{2}$ Our aim is to exploit this dataset and advance the competition and financial access debate further to informal firms. This is because these firms are pervasive in SSA, contributing close to 55\% to GDP and 80\% to employment (Ncube 2013) and thus addressing the challenges they face is important in driving the continent's growth. Extant studies have identified access to finance as being the major impediment faced by small-to-medium enterprises (formal or informal) as they seek to grow. This means that the continued growth of firms (formal or informal) can be sustained if there is reliable and affordable funding.

Against this backdrop, this study therefore examines how SSAs' bank market structure has impacted on the financing of informal firms and what are the other firm-level factors constraining informal firms from accessing bank funding? Understanding the characteristics of both borrowers and lenders in enhancing financial access will help SSA governments design appropriate policy interventions.

\section{Theoretical Literature}

In the theoretical literature, there are two competing hypotheses used to explain the relationship between competition and financial access. The market power hypothesis argues that competition reduces the cost of finance and increases the availability of credit (Love and Peria 2014). This hypothesis draws largely from the quiet life hypothesis, which states that firms in monopolistic markets are more risk averse than firms in competitive markets. Increasing competitive pressure in a monopolistic market

2 This study looks at 14 SSA countries whose surveys were carried out between 2009 and 2018 . We dropped surveys done before 2009 as they are a bit old. 


\section{Moyo, Sibindi}

may enhance financial access. On the contrary, the information hypothesis contends that competitive banking markets can weaken relationship building by depriving banks of the incentive to invest in soft information ${ }^{3}$ (Carbo-Valverde et al. 2008). Thus, a competitive environment makes it easy for customers to switch service providers, increasing the cost of screening and monitoring of borrowers as well as the cost of retaining old and attracting new clients (Love and Peria 2014). In this case, less competitive markets may be associated with more credit availability or improved financial access (Petersen and Rajan 1995). Therefore, an increase in the degree of competition may have two effects. It may worsen moral hazards and adverse selection problems, leading to higher interest rates and reduced availability of credit, or may instead improve financial access to opaque informal firms.

The empirical literature provides mixed results on the nature of the relationship between bank competition and financial access. Most of these studies are on small and mediumsized firms in the formal sector, with studies on the informal sector firms, particularly in Africa, being scarce mostly because of data availability. The bank competition and firm financial access literature can be summarised based on whether the results support the market power hypothesis or the information-based hypothesis. Recent studies that support the market power hypothesis include: Ryan, O'Toole, and McCann (2014) who used European data; Chong, Lu, and Ongena (2013) on Chinese small and medium sized firms; Carbo-Valverde et al. (2008) on Spanish firms; and Beck et al. (2003) who used a database of 74 developing and developed countries. They found that concentration increases obstacles to finance, mainly in countries with low levels of an economic and institutional environment as well as inefficient credit registry. Love and Peria (2014) found similar results, using formal firms' data from 53 developing and developed countries, concurring that quality and scope of credit information sharing mechanisms, such as the use of a credit bureau or registry, reduce the cost of finance, minimise adverse selection, moral hazards and thus mitigate the impact of low competition. Rice and Straham (2008) went further using United States data and showed that small firms borrow at lower interest rates in states that are more open to bank branching. Leon (2014), also using World Bank form enterprise survey data from 69 low and middleincome countries, looked at whether bank competition alleviated credit constraints, finding that competition not only leads to less severe loan approval decisions but also reduces borrower discouragement. Owen and Pereira (2016) support Beck et al. (2003) that foreign-owned banks, restrictions or heavy regulation of bank activities and more government interference exacerbate the impact of concentration on poor financial inclusion. Their results indicate that big banks are consistent with broad financial inclusion, as long as the market remains contestable.

Studies that support the information-based hypothesis also abound. Petersen and Rajan (1995), using a cross section of US formal firms, found that increased concentration is

3 Bank use two types of information (hard and soft information). Hard information is quantitative and obtainable using balance sheets income statements, score cards etc., while soft information is qualitative and informed by bank borrower relationship (judgement, opinions notes, reports, etc.). 


\section{Moyo, Sibindi}

associated with greater access to finance and their results were consistent with those found by Fischer (2000) using a cross section of German manufacturing firms. Rice and Straham (2008) found that in the US, an increase in bank competition might force prices down by reducing profit margins without expanding the amount banks will lend to firms. This is because even though firms might like to borrow at lower prices, lenders rationally understand that those with the greatest demand are likely to be highest in risk. In this case, small firms' ability to raise external finance will continue to bind, even though competition has improved and the cost of borrowing has fallen. Although Tacneng (2014) and Gonzalez and Gonzalez (2008) find results in line with the information hypothesis, a major concern with their studies is that they proxied competition using market concentration alone, and these are not the best proxies of competition. Concentration ${ }^{4}$ ratios do not consider the number and size distribution of firms that are not included in the calculation of the ratio (Lipczynski, Wilson, and Goddard 2017). Claessens and Laeven (2004) also argue that the degree of contestability determines bank competition and that concentration is not a good predictor of competition. Beck et al. (2003) also argue that proxies used to measure the concentration ratio are ambiguous because they ignore the relationship between market contestability and revenue at the bank-level. Moreover, the direction of causality running from structure to conduct is not clear and concentration ratios are not necessarily related to the level of competitiveness in an industry (Baumol 1982). Secondly, the contestable market theory emphasises that a highly concentrated market can be highly competitive, even if a few firms dominate it (Baumol 1982). Due to these reasons, Schaeck et al. (2009) argue that it is inappropriate to rely on concentration to assess the degree of competition in banking, since there is no strong theoretical support for the notion that in markets that are more concentrated, market power is higher, and competition is lower. However, past evidence based on studies that used concentration measures as proxies for competition, is also mixed. For example, Petersen and Rajan (1995) and Fischer (2000) find that higher concentration is associated with greater credit availability, whereas Zarutskie (2003), Beck et al. (2003), and Chong et al. (2013 find the reverse. Our study will, therefore, only employ the two commonly used competition measures, the Lerner index and the Boone indicator.

The impact of bank mergers on access to finance is also explored in the literature, and it is found that bank mergers in general reduce competition. Erel (2011) shows that although bank mergers can generally benefit borrowers through lower interest rates, if the geographical overlap between merging banks is extensive enough to significantly increase concentration in banking markets, spreads normally increase after mergers. Rice and Strahan (2010) exploit the geographical variation in branching restrictions across US states and find that in states that are more open to branching, small firms are more likely to borrow and do so at lower rates. However, the authors find that there are no effects on the amount that small firms can borrow. Zarutskie (2003) argues that the

4 Concentration ration is measured as $C R_{n}=$ $\sum_{i=1}^{n} S_{i}$ where $S_{i}$ is the share of the ith largest firms in total industry sales. 


\section{Moyo, Sibindi}

degree to which banks compete is a potentially important factor in how financial markets allocate capital to the firms and entrepreneurs, the future drivers of growth. She found that greater bank competition in the US increased financial constraints for newly formed firms and these effects diminished and ultimately reversed as firms aged.

Studies done specifically using only African firms are sparse. Ayalew and Xianzhi (2019) examined the effect of bank competition on credit constraints by employing a sample of 9632 formal firms from 27 African countries, and using the data set from the World Bank's Enterprise Surveys. Their results documented that bank competition exacerbated the financing constraints, which supported the information hypothesis. Mengistu and Perez-Saiz (2018) looked at the impact of bank competition on financial inclusion, using individual level data from SSA countries, and found that competition affects financial inclusion and that less competition makes it expensive for individuals to adopt bank accounts, debit and credit cards.

These studies basically show that the relationship between bank competition and financial access is mixed, as some support the information hypothesis while others support the market power hypothesis; and these results also depend on the competition indicator used. There is also a paucity of studies in this area on Africa and on the informal sector. Love and Peria (2014) used formal firms in 53 countries, 12 of which were from SSA, while Leon (2014) covered formal firms in 69 developing and emerging countries, of which 23 were from SSA. This is the gap that we are trying to fill with this study. Table 1 also shows that about $46 \%$ of informal firms in this study identified access to credit as an obstacle to doing business. This figure is even higher in countries like Kenya, Madagascar, Mauritius, Rwanda and Zimbabwe. Understanding factors that affect the efficient supply of credit, like bank competition, is not only an important growth strategy but vital for livelihood protection.

\section{Profile of Firms in the Study Countries}

The data used in this study are from the World Bank informal sector enterprise surveys. These surveys currently cover about 24 countries, all from the developing world; 17 of these countries are in Africa and the rest are from North and South America as well as Asia. We use comparable standardised data from 14 SSA countries surveyed between 2009 and 2018. Our data are cross sectional and composed of 4019 firms. The coverage of firms in each country varies widely, with Botswana contributing the least-about 99 firms compared to Ghana's 729 (see table 1). We use this dataset to collect firm-specific indicators on financial access and other firm-specific variables. 


\section{Moyo, Sibindi}

Table 1: General firm-level descriptive statistics based on the World Bank informal enterprise surveys

\begin{tabular}{|c|c|c|c|c|c|c|c|}
\hline & 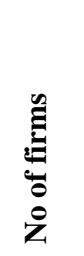 & 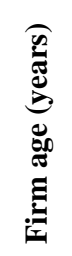 & 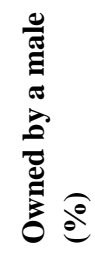 & 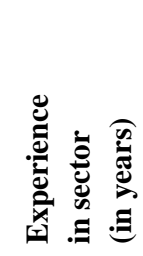 & 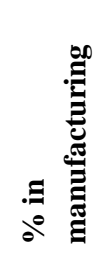 & 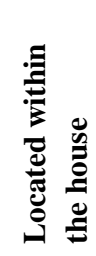 & 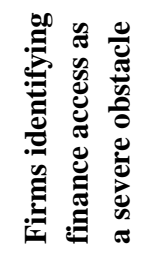 \\
\hline Angola (2010) & 119 & 6.0 & 68.9 & 7.8 & 45.4 & 35.3 & 28.6 \\
\hline Botswana (2010) & 99 & 5.9 & 56.7 & 7.6 & 44.4 & 40.4 & 0 \\
\hline Burkina Faso (2009) & 120 & 8.9 & 78.3 & 10.8 & - & 28.3 & 53.3 \\
\hline Cabo Verde (2009) & 129 & 9.2 & 37.2 & 11.9 & - & 55.8 & 0 \\
\hline Cameroon (2009) & 122 & 7.3 & 66.4 & 9.5 & - & 12.3 & 30.3 \\
\hline DRC (2013) & 480 & 7.2 & 77.1 & 9.5 & 47.9 & 20.4 & 33.7 \\
\hline Ghana (2013) & 729 & 8.6 & 37.2 & 9.5 & 44.2 & 19.8 & 53.0 \\
\hline Kenya (2013) & 533 & 6.5 & 61.1 & 8.1 & 48.4 & 13.3 & 63.8 \\
\hline Madagascar (2009) & 127 & 7.3 & 50.8 & 7.3 & 39.2 & 27.6 & 62.2 \\
\hline Mali (2010) & 120 & 9.4 & 80.8 & 11.7 & 50.8 & 14.2 & 0 \\
\hline Mauritius (2009) & 132 & 15.3 & 69.5 & 18.3 & 50.8 & 50.8 & 63.4 \\
\hline $\begin{array}{l}\text { Rwanda (2011) } \\
\text { Mozambique (2018) } \\
\text { Zimbabwe (2016) }\end{array}$ & $\begin{array}{l}240 \\
554 \\
515\end{array}$ & $\begin{array}{l}5.6 \\
5.2 \\
6.9\end{array}$ & $\begin{array}{l}65.4 \\
46.3 \\
56.6\end{array}$ & $\begin{array}{l}7.4 \\
6.5 \\
7.7\end{array}$ & $\begin{array}{l}68.3 \\
9.0 \\
19.2\end{array}$ & $\begin{array}{l}20.4 \\
72.8 \\
20.0\end{array}$ & $\begin{array}{l}78.4 \\
- \\
76.7\end{array}$ \\
\hline Total & 4019 & 7.3 & 55.8 & 8.9 & 48.8 & 27.1 & 46.4 \\
\hline
\end{tabular}

Source: Author's calculation based on World Bank enterprise data

The statistics in table 1 above and table 2 below show that most of the informal firms are generally young, with an average age of eight years. About $56 \%$ of these firms are owned by a male or have a man as the primary owner of the business. However, more than $50 \%$ of the firms in Cabo Verde and Ghana have a woman as the primary owner. 
Table 2: Firm-level financial access statistics

\begin{tabular}{|c|c|c|c|c|c|c|}
\hline & 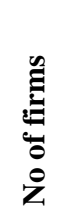 & 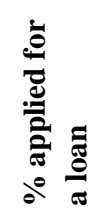 & 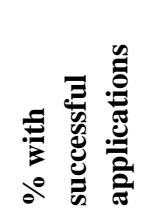 & 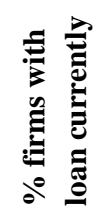 & 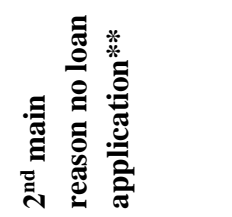 & 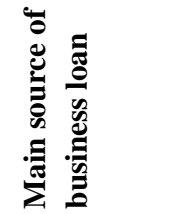 \\
\hline Angola (2010) & 119 & 14.7 & 17.7 & 4.4 & Steps complex & Banks \\
\hline Botswana (2010) & 99 & 7.2 & 14.3 & 2.1 & No guarantee & - \\
\hline $\begin{array}{l}\text { Burkina Faso } \\
(2009)\end{array}$ & 120 & 13.5 & 25.0 & 5.0 & No need & Banks \\
\hline Cabo Verde (2009) & 129 & 8.5 & 45.5 & 7.0 & Interest rate high & Banks \\
\hline Cameroon (2009) & 122 & 18.9 & 39.1 & 16.4 & Steps complex & Moneylenders \\
\hline DRC (2013) & 480 & 11.1 & 32.1 & 5.7 & Steps complex & Microfinance \\
\hline Ghana (2013) & 729 & 18.3 & 50.8 & 10.4 & Interest rate high & Microfinance \\
\hline Kenya (2013) & 533 & 10.4 & 51.9 & 8.8 & No need & Microfinance \\
\hline Madagascar (2009) & 127 & 12.0 & 26.7 & 6.3 & No need & Microfinance \\
\hline Mali (2010) & 120 & 16.7 & 31.6 & 6.7 & No guarantee & Microfinance \\
\hline Mauritius (2009) & 132 & 9.3 & 41.7 & 13.9 & Steps complex & Banks \\
\hline $\begin{array}{l}\text { Rwanda (2011) } \\
\text { Mozambique (2018) } \\
\text { Zimbabwe (2017) } \\
\end{array}$ & $\begin{array}{l}240 \\
554 \\
515\end{array}$ & $\begin{array}{l}17.5 \\
8.5 \\
3.1\end{array}$ & $\begin{array}{l}37.5 \\
---- \\
---\end{array}$ & $\begin{array}{l}8.9 \\
5.4 \\
1.2\end{array}$ & $\begin{array}{l}\text { Interest rate high } \\
\text { Interest rate high } \\
\text { Interest rate high }\end{array}$ & $\begin{array}{l}\text { Microfinance } \\
\text { Moneylenders } \\
\text { Microfinance }\end{array}$ \\
\hline
\end{tabular}

Source: Author's calculation based on World Bank enterprise data. ${ }^{* *}$ The first main reason for almost all the countries is "no need" for loan

The experience of the primary owner is on average 10 years and this figure is relatively high amongst firms in Mauritius (18 years), followed by Carbo Verde (11.9 years). In terms of education, about $38 \%$ of owners have secondary education, with only $6 \%$ having no education at all. The number of owners without education is high in Mali (25\%), while the percentage with primary education is also high in Rwanda (60\%). Owners with secondary education are $63 \%$ in Mauritius, with Kenya having more owners with vocational education at 33\%. Angola and the Democratic Republic of Congo (DRC) have the highest number of owners with university education at $26 \%$ and $25 \%$ respectively. These statistics do not show a clear association between experience and education, except in Mauritius where we have the highest number of owners with secondary education and years of experience compared to other countries. Firm age also appears to be closely associated with the experience of the owner, suggesting that wealth of experience in the sector positively affects a firm's longevity.

Most of the firms in the informal sector in these study countries are in the services sector (51\%), except in Mali, Mauritius and Rwanda. This may probably explain why many of 


\section{Moyo, Sibindi}

these informal businesses are located outside the owners' houses. ${ }^{5}$ More than $50 \%$ of firms in Mozambique, Cabo Verde, and Mauritius are located within the house and when we juxtapose this with the percentage of firms with loans, we find that Mauritius has the highest number of firms with loans as well as successful loan applications. The developed nature of the financial sector in Mauritius could also be the driving force behind these many loans advanced to informal firms, indirectly supporting the fact that bank competition is important. It is possible that the level of financial development in Mauritius, instead of location, could be influencing this association. Cameroon and Kenya, with more firms located outside the house, also have below average success rates in loan applications (see table 2). About $15 \%$ of the firms in the sample had applied for a loan in the previous year and of these $53 \%$ had successful loan applications. However, only $11 \%$ of firms had loans at the time of the surveys, and of these firms $71 \%$ of them had applied for a loan in the previous year, while the remaining $29 \%$ already had running loans. The main sources of loans appear to be banks and microfinance institutions, while the main reasons why some firms did not apply for a loan was because of the high interest rates, complex application processes, lack of collateral, as well as no need for the loan.

\section{Research Methodology, Data and Variables Used}

\section{Data}

The data used in this study combine cross-sectional firm-level data from the World Bank enterprises surveys together with country-level data from the World Development Indicators (2018), Global Financial Development database (2016-2019), World Governance Indicators (2018) and World Economic Outlook databases. Time series data on these informal firms are not available, as the surveys were only conducted once in each African country and this means that our data vary only across firms and countries and there are no dynamic changes captured. Reliable survey data on informal firms, especially in Africa, are hard to find, but the size of the dataset of more than 2000 firms is large enough for econometric analysis. Some firms were dropped because of data inconsistencies or missing observations on the variables of interest. In most cases, data on the sales experience of the owner were missing and thus dropped from the analysis. The firms were surveyed between 2009 and 2018 and provide recent informal survey data publicly available in these countries. The countries are also heterogeneous in that they are a mix of upper middle income, lower middle income and lower income countries. ${ }^{6}$

\section{Measuring Credit Access}

To identify firms with credit access, we refer to a question regarding the credit experience of the firm in the year before the survey. This methodology follows previous

5 Services include hairdressing, cleaning and washing, transport, internet services, street vending, construction, etc.

6 We use the 2018 United Nations Income classification categories. 
contributions by Brown et al. (2011); Cole and Dietrich (2012); Popov and Udell (2012); Leon (2014) and Love and Peria (2014). The main question is: In the last year, did this business or activity apply for any loans? The response to this question is either a YES or NO, and we use this to create our binary dependent variable. The survey goes on to ask about the main reason why the business did not apply for a loan and the responses are grouped into: no need for a loan, suggesting that the firm is probably not credit constrained; interest rates too high; no collateral; the application process is complex; and lack of firm registration. The latter reasons represent credit constrained firms who will probably benefit if the level of bank competition improves.

\section{Measuring Bank Competition}

The aim of this study was to investigate the impact of banking competition on firms' access to finance; therefore, the choice of the appropriate proxy for bank competition is therefore crucial. There are so many techniques used to measure bank competition, ranging from the Five Banks Concentration ratio, the Panzar Rose H statistic, the Lerner index, and the Boone indicator. ${ }^{7}$ The concentration ratio is the simplest measure of competition, which looks at the percentage of the bank market owned by the five largest banks. Its caveat, though, is that it assumes that oligopoly bank markets are less competitive. This is refuted by the theory of contestable markets, which uses the Betrand model to illustrate a competitive equilibrium where firms operate where marginal cost is equal to price. The Lerner index, on the other hand, measures the difference between bank output price and marginal cost - the larger the difference the less competitive is the market. The Boone indicator is the most recent measure of competition, developed in 2008 to overcome some shortcomings of the Lerner index. ${ }^{8}$ The Boone indicator is calculated as the elasticity of profits to marginal costs, and is either negative or positive with more efficient banks achieving higher profits. The more negative the Boone indicator, the higher the level of bank competition. Bank competition is not a firm but country-level indicator that varies, though slowly, from one country to another. Since our dataset does not vary over time, our econometric analysis will exploit the countrylevel variation of this indicator. The degree of variation of country-level variables will be different from that of firm-specific variables in our model, with the former constrained by the availability of data. At the moment there are only 14 African countries with comparable informal firms' data collected by the World Bank. The Global Development Finance database is the source used for all competition variables. Firm survey years were used to collect the data and the values of these competition variables were lagged by one year.

7 We use these different measures of competition for robustness purposes, but the Boone indicator is the most recent and better measure.

8 Although the Lerner index has been widely used in the empirical literature, the theoretical foundations of the index as a competition measure are not robust (Boone 2008). Amir (2000), Bulow and Klemperer (1999), Rosenthal (1980) and Stiglitz (1989), for example, present models where more intense competition leads to higher instead of lower Lerner index values. 


\section{Moyo, Sibindi}

\section{Empirical Model}

The goal of this study was to analyse the impact of bank competition on informal firms' access to credit using selected SSA countries. The approach followed here is closely similar to that used by researchers, inter-alia, Love and Peria (2014); Leon (2014); and Ayalew and Xhianzhi (2019) but the main difference is that these focused mainly on formal firms in both developed and developing countries, including Africa. Igan, Mirzaei, and Moore (2018) also developed a theoretical model based on the work done by Hay and Liu (1997), where they show the relationship between better access to firms, creation of new firms and fall in price cost margins proxy for competition. ${ }^{9}$ The main argument is that informal firms are the most vulnerable and financially neglected group of firms, and measures to improve their access to credit by enhancing bank competition will help improve their productivity and also protect the livelihoods of so many families.

Since our dependent variable is a dummy, we used the following binary choice model for estimation:

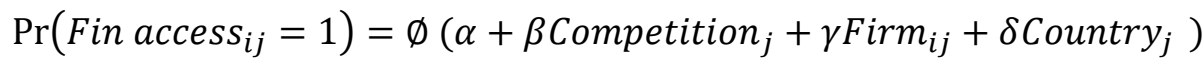

Where Fin access is a financial access dummy, taking a value of one if the firm has a loan, and zero otherwise. The competition variable measures bank competition at country level and is proxied by the Lerner index, Boone indicator, the five-bank concentration ratio (CR5), and the Panzar Rose H-statistic. The firm variable captures relevant firm-specific characteristics, while the country variable captures all other country-level (non-bank competition) indicators used in the study, such as inflation, credit registries, financial development, GDP per capita, rule of law, number of individuals or firms in the public registry or private credit bureaus, etc.

Thus, our estimates will capture cross-country variation in the relationship between bank competition and access to finance. We also assume that country-level measures of bank competition are exogenous to the firm-level measure of access to finance. Thus, each individual firm is not large enough to affect country-level measures of bank competition. However, to mitigate any possible reverse causality concerns, we use oneyear lagged values for both bank competition and the other country-level control variables.

9 We do not reproduce this theoretical model here to save space and also because doing so, adds little value to the paper. 
Moyo, Sibindi

Table 3: List of variables used and expected signs

\begin{tabular}{|l|l|l|}
\hline Variables used & Description & Expected sign \\
\hline 5 bank concentration & Competition variable & negative \\
\hline H statistic & Competition variable & positive \\
\hline Lerner index & Competition variable & negative \\
\hline Boone indicator & Competition variable & negative \\
\hline Firm size & $\begin{array}{l}\text { Firm output converted using relevant exchange } \\
\text { rate (year survey done) }\end{array}$ & positive \\
\hline Firm age & 2019 less year business was formed & positive \\
\hline Firm location & Dummy :1 = within the house, zero otherwise & positive \\
\hline Experience of owner & Number of years in sector & positive \\
\hline Education & Ranges from 1=None to 5 = University & positive \\
\hline Gender & Dummy: 1 = male and 0 = female & positive \\
\hline Inflation & Macroeconomic stability & negative \\
\hline GDP per capita & General level of income & positive \\
\hline Rule of law & $\begin{array}{l}\text { Proxy confidence in contract enforcements, courts } \\
\text { credibility etc. High rule of law value= high } \\
\text { confidence }\end{array}$ & positive \\
\hline Broad Money to GDP & Measure of financial development & positive \\
\hline Private credit bureau & $\begin{array}{l}\text { Measures information asymmetry adults/firms } \\
\text { listed in private credit registries }\end{array}$ & positive \\
\hline Public registry & $\begin{array}{l}\text { Measures information asymmetry: adults/ firms } \\
\text { listed in public credit registries }\end{array}$ & positive \\
\hline
\end{tabular}

\section{Results Analysis}

Table 4 below presents baseline results, using three alternate binary choice models for robust ness purposes. We first control for firm-level indicators and competition measures only. The coefficients shown using the maximum likelihood models are marginal effects and luckily our linear probability model coefficients fall between zero and one. Since we are using cross-sectional data we are only exploiting the crosssectional (country-level) variation in the competition indices to ascertain the impact on financial access. These baseline results show that the Lerner index is consistently positive and significant, and this supports the information hypothesis. On the other hand, the Boone indicator is also consistently negative and significant at $1 \%$ and this supports the market power hypothesis. The marginal effects of the Lerner index appear to be larger than the ones for the Boone indicator. 
Table 4: Financial access and firm-level indicators (baseline models)

\begin{tabular}{|c|c|c|c|c|c|c|}
\hline Variables & $\begin{array}{l}\text { Model } 1 \\
(\text { LPM }) \\
\end{array}$ & $\begin{array}{l}\text { Model } 2 \\
\text { (Logit) }\end{array}$ & $\begin{array}{l}\text { Model 3 } \\
\text { (Probit) }\end{array}$ & $\begin{array}{l}\text { Model } 4 \\
(\text { LPM) }\end{array}$ & $\begin{array}{l}\text { Model } 5 \\
\text { (Logit) }\end{array}$ & $\begin{array}{l}\text { Model } 6 \\
\text { (Probit) }\end{array}$ \\
\hline Lerner & $\begin{array}{l}0.385^{* * *} \\
(0.051)\end{array}$ & $\begin{array}{l}0.369 * * * \\
(0.047)\end{array}$ & $\begin{array}{l}0.377 * * * \\
(0.049)\end{array}$ & & & \\
\hline Boone & & & & $\begin{array}{l}-0.166 * * * \\
(0.046)\end{array}$ & $\begin{array}{l}-0.179 * * * \\
(0.051)\end{array}$ & $\begin{array}{l}-0.182 * * * \\
(0.049)\end{array}$ \\
\hline $\begin{array}{l}\text { Experience of } \\
\text { owner }\end{array}$ & $\begin{array}{l}0.003 * * \\
(0.001) \\
\end{array}$ & $\begin{array}{l}0.003 * * \\
(0.001)\end{array}$ & $\begin{array}{l}0.003 * * \\
(0.001)\end{array}$ & $\begin{array}{l}0.003 * * \\
(0.001) \\
\end{array}$ & $\begin{array}{l}0.003 * * \\
(0.001)\end{array}$ & $\begin{array}{l}0.003 * * \\
(0.001) \\
\end{array}$ \\
\hline Firm age & $\begin{array}{l}-0.002 * \\
(0.001)\end{array}$ & $\begin{array}{l}-0.002 * \\
(0.001)\end{array}$ & $\begin{array}{l}-0.002 * \\
(0.001) \\
\end{array}$ & $\begin{array}{l}-0.002 * \\
(0.001)\end{array}$ & $\begin{array}{l}-0.002 * \\
(0.001) \\
\end{array}$ & $\begin{array}{l}-0.002^{*} \\
(0.001)\end{array}$ \\
\hline Firm size & $\begin{array}{l}0.004 \\
(0.003) \\
\end{array}$ & $\begin{array}{l}0.053 \\
(0.038) \\
\end{array}$ & $\begin{array}{l}0.004 \\
(0.005) \\
\end{array}$ & $\begin{array}{l}0.002 \\
(0.003) \\
\end{array}$ & $\begin{array}{l}0.002 \\
(0.003) \\
\end{array}$ & $\begin{array}{l}0.002 \\
(0.003) \\
\end{array}$ \\
\hline Firm location & $\begin{array}{l}0.025^{*} \\
(0.011)\end{array}$ & $\begin{array}{l}0.025^{*} \\
(0.012)\end{array}$ & $\begin{array}{l}0.029 * \\
(0.012)\end{array}$ & $\begin{array}{l}0.010 \\
(0.011)\end{array}$ & $\begin{array}{l}0.009 \\
(0.011)\end{array}$ & $\begin{array}{l}0.010 \\
(0.011)\end{array}$ \\
\hline Education & $\begin{array}{l}0.009 \\
(0.005)\end{array}$ & $\begin{array}{l}0.009 \\
(0.005) \\
\end{array}$ & $\begin{array}{l}0.009 \\
(0.005)\end{array}$ & $\begin{array}{l}0.016^{* *} \\
(0.005) \\
\end{array}$ & $\begin{array}{l}0.015 * * \\
(0.005) \\
\end{array}$ & $\begin{array}{l}0.016^{* *} \\
(0.005) \\
\end{array}$ \\
\hline $\begin{array}{l}\text { Gender of } \\
\text { owner }\end{array}$ & $\begin{array}{l}-0.011 \\
(0.010)\end{array}$ & $\begin{array}{l}-0.010 \\
(0.010)\end{array}$ & $\begin{array}{l}-0.009 \\
(0.011)\end{array}$ & $\begin{array}{l}-0.021 * * \\
(0.010)\end{array}$ & $\begin{array}{l}-0.021 * * \\
(0.010)\end{array}$ & $\begin{array}{l}-0.021 * * \\
(0.010)\end{array}$ \\
\hline Observations & 2654 & 2654 & 2654 & 2654 & 2654 & 2654 \\
\hline No of countries & 14 & 14 & 14 & 14 & 14 & 14 \\
\hline
\end{tabular}

Notes: The estimated regressions exclude country-level indicators. The corresponding robust standard errors are in parentheses. $* * * \mathrm{p}<0.01$, ** $\mathrm{p}<0.05$, * $\mathrm{p}<0.1$. The access to finance variable is a dummy taking the value of one, when the firm states that it has a loan, and zero otherwise. All values are marginal effects. LPM is Linear Probability Model. Dependent variable is a dummy taking the value of one if the firm currently has a loan, and zero otherwise. Firm location takes the value of one if the firm is located within the house and zero otherwise. Gender is also a dummy taking the value of one if the owner is male, and zero otherwise. Education is a categorical variable taking the value of one if the owner has no education, two if the owner has primary education, three for secondary education, four for vocational education and five for university education. The coefficients of the experience and age variables appear constant because of rounding off. They are different when not rounded off to three decimal places.

The firm-level variables also show consistent results and their impact is independent of the competition indicator used. Firm owners' experience in the sector is positive and significant, even though the marginal impact is very small. The years of experience working in a sector are of advantage and demonstrate the owner's good understanding of the business and should, therefore, make the borrower more attractive to the lender. Prior working experience tends to help the entrepreneur understand the competitive nature of the environment, particularly in the case of an enterprise established within the same industry in which the entrepreneur has been previously employed. Ezeoha and Botha (2012) argue that advancement in age is associated with reputation, experience and asset base. Thus, older firms stand a chance of building a strong asset base, gaining an attractive industry reputation and acquiring experience on the workings of financial markets. Firm age, therefore, appears to negatively affect the probability of getting a loan. Education is also helpful in easily compiling and providing all the necessary 


\section{Moyo, Sibindi}

business information lenders require before advancing financial assistance. Individuals with relatively higher levels of educational background should be particularly well suited for working in analytical and logic-based disciplines such as entrepreneurship, have the potential to run a successful business, and are less risky. The education variable is positive and significant in some of the above models. The fact that the variable is not consistently significant may mean that an experienced owner does not necessarily need to be educated. The long history of working in the sector equips one with requisite knowledge of the sector as well as how to navigate financial markets. Education is a necessary but not a sufficient condition to enhance access to finance.

Although gender has been discussed and singled out as the most important issue when it comes to financial access in developing countries (Narain 2009), this variable is negative and insignificant, suggesting that the probability of accessing finance is higher when you are female, and this partly contradicts conventional wisdom. Narain (2009) argues that while both men and women face similar barriers, these barriers are higher for women, because of culture, lack of traditional collateral (land and property often registered in man's name), women's lower income levels relative to men, and financial institutions' inability to design appropriate products to cater for women's needs. Evidence from many studies has always shown that globally, women's access to finance compared to men is lower (Bardasi, Blackden, and Guzman 2007; Demirguc-Kunt, Beck and Hornohan 2008; Diagne, Zeller, and Sharma 2000; Richardson, Rhona, and Finnegan 2004). The theoretical hypothesis in the case of location is that informal firms located within the house of the owner are less risky to fund than those located outside. This is because informal firms are not registered by nature and this may make it difficult for lenders to trace them, should they default and close shop, if they are operating from temporary business premises. The location variable is generally positive and significant in line with expectation.

The study goes further in table 5 , and controls for more country-level heterogeneity by including GDP per capita, inflation, rule of law, and level of financial deepening. The study continues to assume that competition is exogenous and beyond the influence of any individual informal firm, and estimates all the equations using the Probit model and report marginal effects. 
Table 5: Models controlling for all competition indicators

\begin{tabular}{|c|c|c|c|c|c|c|}
\hline Variables & Model 1 & Model 2 & Model 3 & Model 4 & Model 5 & Model 6 \\
\hline Lerner & $\begin{array}{l}0.464 * * * \\
(0.051)\end{array}$ & $\begin{array}{l}0.476 * * * \\
(0.059)\end{array}$ & $\begin{array}{l}0.546 * * * \\
(0.057)\end{array}$ & & & \\
\hline Boone & & & & $\begin{array}{l}-0.351 * * * \\
(0.075)\end{array}$ & $\begin{array}{l}-0.148^{*} \\
(0.085) \\
\end{array}$ & $\begin{array}{l}-0.148^{*} \\
(0.082) \\
\end{array}$ \\
\hline H statistic & & $\begin{array}{l}0.038 \\
(0.056) \\
\end{array}$ & & & $\begin{array}{l}0.030 \\
(0.056)\end{array}$ & \\
\hline Concentration 5 & & & $\begin{array}{l}0.002 * * * \\
(0.0004)\end{array}$ & $\begin{array}{l}0.001 \\
(0.001)\end{array}$ & & \\
\hline $\begin{array}{l}\text { Bank } \\
\text { concentration }\end{array}$ & $\begin{array}{l}0.003 * * * \\
(0.001)\end{array}$ & & & & & $\begin{array}{l}0.0003 \\
(0.0004)\end{array}$ \\
\hline $\begin{array}{l}\text { Experience of } \\
\text { owner }\end{array}$ & $\begin{array}{l}0.002 * * \\
(0.001)\end{array}$ & $\begin{array}{l}0.002 * * \\
(0.001)\end{array}$ & $\begin{array}{l}0.002 * * * \\
(0.001)\end{array}$ & $\begin{array}{l}0.002 * * \\
(0.001)\end{array}$ & $\begin{array}{l}0.002 * * \\
(0.001)\end{array}$ & $\begin{array}{l}0.003^{* * * *} \\
(0.001)\end{array}$ \\
\hline Firm age & $\begin{array}{l}-0.0004 \\
(0.001)\end{array}$ & $\begin{array}{l}-0.001 \\
(0.001)\end{array}$ & $\begin{array}{l}-0.0004 \\
(0.001)\end{array}$ & $\begin{array}{l}-0.001 \\
(0.0009)\end{array}$ & $\begin{array}{l}-0.001 \\
(0.001)\end{array}$ & $\begin{array}{l}-0.001 \\
(0.001)\end{array}$ \\
\hline Firm size & $\begin{array}{l}0.005 \\
(0.003)\end{array}$ & $\begin{array}{l}0.011 * * * \\
(0.003)\end{array}$ & $\begin{array}{l}0.005 \\
(0.003)\end{array}$ & $\begin{array}{l}0.005 \\
(0.003)\end{array}$ & $\begin{array}{l}0.004 \\
(0.003)\end{array}$ & $\begin{array}{l}0.005 \\
(0.003)\end{array}$ \\
\hline Firm location & $\begin{array}{l}0.024^{*} \\
(0.014)\end{array}$ & $\begin{array}{l}0.019 \\
(0.013)\end{array}$ & $\begin{array}{l}0.025^{* *} \\
(0.012)\end{array}$ & $\begin{array}{l}0.015 \\
(0.012)\end{array}$ & $\begin{array}{l}0.008 \\
(0.012)\end{array}$ & $\begin{array}{l}0.010 \\
(0.011)\end{array}$ \\
\hline Education & $\begin{array}{l}0.004 \\
(0.005)\end{array}$ & $\begin{array}{l}-0.002 \\
(0.005)\end{array}$ & $\begin{array}{l}0004 . \\
(0.005)\end{array}$ & $\begin{array}{l}0.012 * * \\
(0.005)\end{array}$ & $\begin{array}{l}0.003 \\
(0.005)\end{array}$ & $\begin{array}{l}0.001 \\
(0.005)\end{array}$ \\
\hline Gender of owner & $\begin{array}{l}-0.024 * * \\
(0.012)\end{array}$ & $\begin{array}{l}-0.024 * \\
(0.012)\end{array}$ & $\begin{array}{l}-0.023^{*} \\
(0.012)\end{array}$ & $\begin{array}{l}-0.024 * * \\
(0.012)\end{array}$ & $\begin{array}{l}-0.027 * * \\
(0.013)\end{array}$ & $\begin{array}{l}-0.025^{* *} \\
(0.012)\end{array}$ \\
\hline Inflation & $\begin{array}{l}-0.003^{* * *} \\
(0.001)\end{array}$ & $\begin{array}{l}-0.034 * * * \\
(0.009)\end{array}$ & $\begin{array}{l}0.009^{* * *} \\
(0.004)\end{array}$ & $\begin{array}{l}-0.003 \\
(0.002)\end{array}$ & $\begin{array}{l}-0.006^{* * *} \\
(0.002)\end{array}$ & $\begin{array}{l}-0.001 \\
(0.003)\end{array}$ \\
\hline GDP per capita & $\begin{array}{l}0.00002^{*} \\
(0.00001)\end{array}$ & $\begin{array}{l}0.0004 * * \\
(0.00001)\end{array}$ & $\begin{array}{l}0.00001 \\
(0.00001)\end{array}$ & $\begin{array}{l}-0.009 \\
(0.006)\end{array}$ & $\begin{array}{l}-0.00001 \\
(0.00001\end{array}$ & $\begin{array}{l}-0.0010 \\
(0.0006)\end{array}$ \\
\hline Rule of law & $\begin{array}{l}-0.018 \\
(0.021)\end{array}$ & $\begin{array}{l}0.060^{*} \\
(0.034)\end{array}$ & $\begin{array}{l}-0.035 \\
(0.022)\end{array}$ & $\begin{array}{l}0.034 \\
(0.023)\end{array}$ & $\begin{array}{l}0.025^{*} \\
(0.015)\end{array}$ & $\begin{array}{l}0.031 \\
(0.020)\end{array}$ \\
\hline $\begin{array}{l}\text { Broad } \\
\text { Money(\%GDP) }\end{array}$ & $\begin{array}{l}0.003 \\
(0.005)\end{array}$ & $\begin{array}{l}-0.004 * * * \\
(0.001)\end{array}$ & $\begin{array}{l}0.0002 \\
(0.0007)\end{array}$ & $\begin{array}{l}-0.0004 \\
(0.0008)\end{array}$ & $\begin{array}{l}0.0006 \\
(0.0007)\end{array}$ & $\begin{array}{l}-0.0001 \\
(0.0006)\end{array}$ \\
\hline Observations & 2654 & 2529 & 2654 & 2654 & 2654 & 2772 \\
\hline No of countries & 14 & 14 & 14 & 14 & 14 & 14 \\
\hline
\end{tabular}

Notes: The corresponding robust standard errors are in parentheses. $* * * \mathrm{p}<0.01, * * \mathrm{p}<0.05, *$ $\mathrm{p}<0.1$. The access to finance variable is a dummy taking the value of one when the firm states that it has a loan, and zero otherwise. Sector dummy takes the value of one if it is manufacturing, and zero if it is services.

After including all the other competition indicators, results still show that the Lerner variable has a consistently positive and significant effect on financial access, suggesting that lower competition improves the probability of getting a loan. Since the level of correlation between the Lerner index and the Boone indicator, as well as the two concentration measures, is relatively high, above 0.5 , (see table 7 appendix) separate models are run for these competition measures. The marginal effects suggest that reduced competition improves a firm's probability to obtain financial access by $50 \%$. The five bank concentration ratio is also positive and significant and, just like the Lerner index, supports the information hypothesis. Although the Lerner index has been widely used in the empirical literature, the theoretical foundations of the index as a competition 


\section{Moyo, Sibindi}

measure are not robust (Boone 2008). Amir (2000), Bulow and Klemperer (1999), Rosenthal (1980) and Stiglitz (1989), for example, present models where more intense competition leads to higher instead of lower Lerner index values. Corts (1999) shows that the estimates of the Lerner index will typically underestimate the price-cost margin and the level of market conduct itself. Boone (2008) argues that their competition measure is theoretically more robust and does not pose more data that are more stringent requirements than the Lerner index. We thus used the Boone indicator and found that it is consistently negative, significant, and supportive of the market power hypothesis. The results of the Boone indicators are supported by those of the Panzar Rose H-statistics, which are also positive and significant. An increase in the $\mathrm{H}$ statistic implies an increase in the level of competition and this improves the probability of funding.

Table 6: Models controlling for information asymmetry

\begin{tabular}{|c|c|c|c|c|c|c|c|}
\hline Variables & Model 1 & Model 2 & Model 3 & Model 4 & Model 5 & Model 6 & Model 7 \\
\hline Lerner & $\begin{array}{l}0.409 * * * \\
(0.097) \\
\end{array}$ & $\begin{array}{l}0.454 * * * \\
(0.103)\end{array}$ & $\begin{array}{l}0.335 * * * \\
(0.035) \\
\end{array}$ & $\begin{array}{l}0.284^{*} \\
(0.169)\end{array}$ & & & \\
\hline Boone & & & & & $\begin{array}{l}-0.154 * * \\
(0.060) \\
\end{array}$ & $\begin{array}{l}-0.148 * * * \\
(0.040)\end{array}$ & $\begin{array}{l}-0.52 * * \\
(0.074) \\
\end{array}$ \\
\hline $\begin{array}{l}\text { Experience of } \\
\text { owner }\end{array}$ & $\begin{array}{l}0.002 * * \\
(0.001)\end{array}$ & $\begin{array}{l}0.002 * * \\
(0.001)\end{array}$ & $\begin{array}{l}0.002 * * * \\
(0.001)\end{array}$ & $\begin{array}{l}0.002 * * \\
(0.001)\end{array}$ & $\begin{array}{l}0.002 * * \\
(0.001)\end{array}$ & $\begin{array}{l}0.016 * * \\
(0.006)\end{array}$ & $\begin{array}{l}0.002 * * \\
(0.001)\end{array}$ \\
\hline Gender & $\begin{array}{l}-0.022 * * \\
(0.010)\end{array}$ & $\begin{array}{l}-0.021 * \\
(0.012)\end{array}$ & $\begin{array}{l}-0.022^{*} \\
(0.011)\end{array}$ & $\begin{array}{l}-0.020^{*} \\
(0.012)\end{array}$ & $\begin{array}{l}-0.026^{* *} \\
(0.011)\end{array}$ & $\begin{array}{l}-0.163^{* *} \\
(0.074)\end{array}$ & $\begin{array}{l}-0.025^{* *} \\
(0.011)\end{array}$ \\
\hline Firm age & $\begin{array}{l}-0.001 * \\
(0.001)\end{array}$ & $\begin{array}{l}-0.001 \\
(0.001)\end{array}$ & $\begin{array}{l}-0.001 \\
(0.001)\end{array}$ & $\begin{array}{l}-0.001 \\
(0.001)\end{array}$ & $\begin{array}{l}-0.001 \\
(0.001)\end{array}$ & $\begin{array}{l}-0.006 \\
(0.006)\end{array}$ & $\begin{array}{l}-0.001 \\
(0.001)\end{array}$ \\
\hline Firm location & $\begin{array}{l}0.023^{*} \\
(0.014)\end{array}$ & $\begin{array}{l}0.024^{*} \\
(0.014)\end{array}$ & $\begin{array}{l}0.025^{*} \\
(0.014)\end{array}$ & $\begin{array}{l}0.021 \\
(0.014)\end{array}$ & $\begin{array}{l}0.009 \\
(0.013)\end{array}$ & $\begin{array}{l}0.050 \\
(0.082)\end{array}$ & $\begin{array}{l}0.008 \\
(0.013)\end{array}$ \\
\hline Education & $\begin{array}{l}0.001 \\
(0.005) \\
\end{array}$ & $\begin{array}{l}0.003 \\
(0.005) \\
\end{array}$ & $\begin{array}{l}0.001 \\
(0.005)\end{array}$ & $\begin{array}{l}0.002 \\
(0.005)\end{array}$ & $\begin{array}{l}0.004 \\
(0.005)\end{array}$ & $\begin{array}{l}0.032 \\
(0.036) \\
\end{array}$ & $\begin{array}{l}0.004 \\
(0.005) \\
\end{array}$ \\
\hline Firm size & $\begin{array}{l}0.009 * * \\
(0.003) \\
\end{array}$ & $\begin{array}{l}0.010 * * * \\
(0.003)\end{array}$ & $\begin{array}{l}0.005 \\
(0.004)\end{array}$ & $\begin{array}{l}0.010 * * * \\
(0.003)\end{array}$ & $\begin{array}{l}0.001 \\
(0.003)\end{array}$ & $\begin{array}{l}0.010 \\
(0.019) \\
\end{array}$ & $\begin{array}{l}0.002 \\
(0.003) \\
\end{array}$ \\
\hline Bank branches & $\begin{array}{l}0.011^{* * * *} \\
(0.004)\end{array}$ & $\begin{array}{l}-0.012 * * * \\
(0.004)\end{array}$ & $\begin{array}{l}0.030 \\
(0.023)\end{array}$ & $\begin{array}{l}-0.011^{* * * *} \\
(0.004)\end{array}$ & $\begin{array}{l}-0.001 \\
(0.002)\end{array}$ & $\begin{array}{l}-0.019 \\
(0.015)\end{array}$ & $\begin{array}{l}0.004 \\
(0.003)\end{array}$ \\
\hline $\begin{array}{l}\text { Private credit } \\
\text { bureau }\end{array}$ & $\begin{array}{l}0.001 \\
(0.001) \\
\end{array}$ & $\begin{array}{l}0.001 \\
(0.001) \\
\end{array}$ & $\begin{array}{l}-0.001 \\
(0.001) \\
\end{array}$ & $\begin{array}{l}-0.004 \\
(0.004) \\
\end{array}$ & $\begin{array}{l}-0.002 * * \\
(0.001) \\
\end{array}$ & $\begin{array}{l}-0.061 \\
(0.065) \\
\end{array}$ & $\begin{array}{l}-0.002^{*} \\
(0.001) \\
\end{array}$ \\
\hline Public registry & $\begin{array}{l}0.012^{* * *} \\
(0.004)\end{array}$ & $\begin{array}{l}0.029 * \\
(0.017) \\
\end{array}$ & $\begin{array}{l}0.006 \\
(0.005)\end{array}$ & $\begin{array}{l}0.013 * * * \\
(0.004)\end{array}$ & $\begin{array}{l}0.003 \\
(0.002)\end{array}$ & $\begin{array}{l}0.019 \\
(0.016) \\
\end{array}$ & $\begin{array}{l}0.004 \\
(0.003) \\
\end{array}$ \\
\hline $\begin{array}{l}\text { Lerner public } \\
\text { registry }\end{array}$ & & $\begin{array}{l}-0.057 \\
(0.059) \\
\end{array}$ & & & & & \\
\hline $\begin{array}{l}\text { Lerner private } \\
\text { bureau }\end{array}$ & & & & $\begin{array}{l}-0.022 \\
(0.025)\end{array}$ & & & \\
\hline $\begin{array}{l}\text { Boone public } \\
\text { registry }\end{array}$ & & & & & $\begin{array}{l}-0.081 * * \\
(0.039)\end{array}$ & & \\
\hline $\begin{array}{l}\text { Boone private } \\
\text { bureau }\end{array}$ & & & & & & $\begin{array}{l}0.460 \\
(0.598)\end{array}$ & \\
\hline Observations & 2654 & 2677 & 2677 & 2654 & 2810 & 2810 & 2810 \\
\hline $\begin{array}{l}\text { No of } \\
\text { countries }\end{array}$ & 14 & 14 & 14 & 14 & 14 & 14 & 14 \\
\hline
\end{tabular}




\section{Moyo, Sibindi}

The next step here is to capture information asymmetry in the credit market and see how it affects financial access. Databases containing credit information of different borrowers are generally used by lenders when advancing credit. In some countries these databases are managed by the government as public credit registries, while in others they are private credit bureaus. Credit information-sharing mechanisms can help overcome adverse selection and moral hazard problems in credit markets (Love and Peria 2014; Padilla and Pagano 2000). Credit reporting allows borrowers to build a credit history and to use a documented track record of responsible borrowing and repayment as "reputational collateral" to access credit outside of established lending relationships (Love and Mylenko 2005). Thus, reliable credit information can serve as a substitute for bank-firm relationships. Several studies have confirmed that information sharing results in more lending and better access to finance (Brown et al. 2009; Djankov et al. 2007; Houston et al. 2010). Results in this study are supportive, showing that reducing or minimising information asymmetry, particularly public credit registries, is good for enhancing informal firms' financial access.

We also interacted some competition indices with information asymmetry. The idea here was to find out how competition impacts credit access if information asymmetry on the credit history of borrowers is low. We also calculated the conditional effects of these variables to measure the overall impact. Results show that the public credit registry ${ }^{10}$ variable is consistently positive and significant in three models, suggesting that it improves the probability of getting a loan. On the other hand, the private credit bureau variable is consistently negative and significant in some cases, implying that it has a negative effect on financial access. These findings are similar to those by Asongu (2017), who found that public credit registries are better for financial access as they reduce loan prices, while the opposite is true for private credit bureaus. According to Asongu (2017), private credit bureaus are still underdeveloped compared to public credit registries in Africa. Table 7 (appendix) shows that only four out of 14 countries used in this study have data on the percentage of adults or firms listed by the private credit bureau. These results are, however, in contrast to those found by Love and Mylenko (2005), who argue that public credit registries have no substantial impact on improving financial access, compared to private credit bureaus.

The impact of public credit registry, given the level of competition, captures the conditional effect of reducing information asymmetry and the net effects are calculated as follows: the net effect obtained from the interaction between the Lerner index and public credit registry (column 3$)$ is $0.010([-0.057 \times 0.33]+[0.029])$, where: 0.029 is the unconditional effect of public credit registry; 0.33 is the mean value of competition measured using the Lerner index, and -0.057 is the conditional effect from the interaction between Lerner index and public credit registry (Brambor, Clark, and Golder

10 This includes number of individuals and firms listed in public credit registry or by a private credit bureau with current information on repayment history, unpaid debts or credit outstanding. The data are from Global Financial Development reports. This helps financial firms make prudent lending decisions. 


\section{Moyo, Sibindi}

06; Tchamyou 2018). In the case of a private credit bureau, the net effect (column 5) is $-0.011([-0.022 \times 0.33]+[-0.004])$. Similarly, using the Boone indicator, the net effect in the case of the public registry is 0.0003 and -0.077 for a private credit bureau. In the case of bank branches, the net effect using the Lerner index is -0.836 (significant) and 0.083 using the Boone indicator, but insignificant. Thus, a reduction in competition accompanied by a reduction in information asymmetry, in the case of public credit registries, improves the probability of funding and the reverse is true for private credit bureaus. Thus, the negative impact of a reduction in competition, in the case of the Boone indicator, is neutralised by the availability of public credit information and leads to improved financial access.

In the case of country-level controls, the inflation variable has an expected sign and is generally negative and significant, suggesting that in a highly uncertain macroeconomic environment, financial institutions are reluctant to lend. GDP per capita is significant but negative in most of the models, suggesting that if incomes increase, the likelihood of getting a loan will decrease. This could mean that firms in the informal sector will use their own sources of finance instead of debt. Thus, if income levels are high (GDP increasing), informal firms may be able to raise their own funding internally from sales instead of borrowing. Statistics in table 2 show that the main reason firms did not apply for a loan was because they did not need one; and that $60 \%$ of firms use their own funds as a source of business finance, with the second main source being friends. This suggests that increasing income levels may reduce the demand for bank loans by informal firms.

In the case of the rule of law, which measures the quality of contract enforcement, property rights and the courts, an increase in the value of this variable indicates better outcomes. In this case, there is generally a positive relationship, suggesting that contract enforcement improves the probability of getting a loan increase. The improved rule of law reduces adverse selection and moral hazards, resulting in owners with a good reputation and the ability to pay when applying for loans and using them productively. The study went further and controlled for financial deepening, but this variable produced mixed signals. The level of sophistication of the country's financial sector (broad money to GDP), which proxies its ability to develop products to meet the needs of various economic agents, is consistently insignificant. Table 8 (appendix) shows that the mean of this variable is $33 \%$, suggesting that financial deepening is still very low in these countries and this probably explains why the variable is insignificant.

\section{Conclusion and Policy Implications}

The overall message coming from the above results is that informal firms with certain characteristics stand a better chance of accessing funding, compared to others. The study found that experience, education, firm size, location within the house, and being a woman, are the main factors that enhance the probability of getting funding. This suggests that lenders are risk averse and will support informal firms which have low chances of defaulting. 


\section{Moyo, Sibindi}

The fact that the Boone indicator is negative and significant, suggests that the market power hypothesis is applicable to SSA and that more competition reduces the cost of finance and increases the availability of credit. Given that the bank sector has been found to be generally uncompetitive and monopolistic, more reforms are needed in the sector. The fact that access to finance is positively related to gender, experience and education, is typical in a less competitive banking environment where banks are not pressured to take risks. Relaxing entry restrictions - to even foreign players - and penalising anti-competitive behaviour should be promoted by the regulatory authorities; however, without compromising bank soundness. The fact that controlling for information asymmetry by using the public credit registry improves the probability of obtaining a loan means that there is a need for government in collaboration with the private sector to create, maintain and improve the coverage of these credit registries, as they are an important source of lending information. The 2019 Global Financial Development database shows that public credit registries in SSA covered only $9 \%$ of the adult population. In the countries covered in this study, the highest coverage was in Cameroon at $40 \%$ and the lowest at zero was in countries like Ghana, Kenya, Mali and Burkina Faso. Private credit bureaus also only cover $11 \%$ of the adult population in SSA. In the sampled countries the figure was high at $54 \%$ in Botswana and zero in six of the 14 countries used in the study. This shows that poor data collection on the credit histories of borrowers, is a problem in SSA and partly contributes to poor financial access.

One last message coming from this study is that there is a need for African governments to collect data on the informal sector, especially given the size and role the sector plays in driving economic activity in the continent. We used 14 SSA countries in this study because reliable and recent public data are not available for other countries on the continent, and this partly affected the representativeness and generalisability of our results. The other major caveat of this study, linked to data unavailability, is that it does not consider dynamic changes in both country-level and firm-level indicators used. Our results do not tell us whether changes in bank competition over time influence access to credit, however, only explain that differences in bank competition levels across countries affect differences in credit access by informal firms. Availability of time series data on these informal firms will allow dynamism to be captured and will thus strengthen the analysis done in this paper. This is, therefore, an opportunity for further research.

\section{References}

Abdelkader, I., and B. F. Mansouri. 2013. "Competitive Conditions of the Tunisian Banking Industry: An Application of the Panzar-Rosse Model." African Development Review 25 (4): 526-536. https://doi.org/10.1111/1467-8268.12047.

Amir, R. 2000. "Market Structure, Scale Economies and Industry Performance.” Discussion Papers 00-08. Department of Economics, University of Copenhagen, Denmark. 


\section{Moyo, Sibindi}

Asongu, S. A. 2017. "The Effect of Reducing Information: A Symmetry on Loan Price and Quantity in The African Banking Industry." Research in International Business and Finance (41): 185-197. https://doi.org/10.1016/j.ribaf.2017.04.020.

Ayalew, M. M., and Z. Xianzhi. 2019. "Bank Competition and Access to Finance: Evidence from African Countries.” Journal of Industry, Competition and Trade 19 (1): 155-184. https://doi.org/10.1007/s10842-018-0283-6.

Banya, R. M., and N. Biekpe. 2017. "Bank Competition and Economic Growth: Empirical Evidence from Selected Frontier African Countries." Journal of Economic Studies 44: 245-265. https://doi.org/10.1108/JES-09-2015-0169.

Bardasi, E., C. M. Blackden, and J. C. Guzman. 2007. “Gender, Entrepreneurship, and Competitiveness in Africa." Africa Competitiveness Report.

Baumol, W. J. 1982. "Contestable Markets: An Uprising of the Theory of Industrial Structure." .American Economic Review 72 (1): 1-15.

Beck, T., A. Demirguc-Kunt, and V. Maksimovic. 2003. "Bank Competition and Access to Finance: International Evidence.” Journal of Money, Credit and Banking 36 (3): 627-648. https://doi.org/10.1353/mcb.2004.0039.

Biekpe, N. 2011. "The Competitiveness of Commercial Banks in Ghana.” African Development Review 26 (1): 75-87. https://doi.org/10.1111/j.1467-8268.2010.00273.x.

Boone, J. 2008. “A New Way to Measure Competition.” The Economic Journal 118: 12451261. https://doi.org/10.1111/j.1468-0297.2008.02168.x.

Brambor, T., W. M. Clark, and M. Golder. 2006. "Understanding Interaction Models: Improving Empirical Analyses.” Political Analysis 14 (1): 1123-1136. https://doi.org/10.1093/pan/mpi014.

Brown, R. J., S Fazzari, and B. Petersen. 2009. "Financing Innovation and Growth: Cash Flow, External Equity, and the 1990s R\&D Boom.” The Journal of Finance 64 (1): 151-185. https:// doi.org/10.1111/j.1540-6261.2008.01431.x.

Brown, M., S. Ongena., A. Popov, and P. Yesin. 2011. "Who Needs Credit and who Gets Credit in Eastern Europe? Economic Policy 26 (65): 93-130. https://doi.org/10.1111/j.1468-0327.2010.00259.x.

Bulow, J., and P. Klemperer. 1999. "Prices and the Winner's Curse.” Rand Journal of Economics 33 (1): 1-21. https://doi.org/10.2307/2696372.

Carbo-Valverde, S., F. Rodriguez-Fernandez, and G. F. Udell. 2008. "Bank Market Power and SME Financing Constraints.” Review of Finance 13: 309-340. https://doi.org/10.1093/rof/rfp003. 


\section{Moyo, Sibindi}

Claessens, S., and L. Laeven. 2004. "What Drives Bank Competition? Some International Evidence." Journal of Money Credit and Banking 36 (3): 563-83.

https://doi.org/10.1353/mcb.2004.0044.

Chong, T. T. L., L. Lu, and S. Ongena. 2013. "Does Banking Competition Alleviate or Worsen Credit Constraints Faced by Small and Medium Enterprises? Evidence from China." Journal of Banking and Finance 37: 3412-3424. https://doi.org/10.1016/j.jbankfin.2013.05.006.

Cole, R., and A. Dietrich. 2012. "SME Credit Availability around the World: Evidence from the World Bank's Enterprise Surveys.” In Midwest Finance Association 2013 Annual Meeting Paper.

Corts, S. K. 1999. "Conduct Parameters and the Measurement of Market Power." Journal of Econometrics 88 (2): 227-250. https://doi.org/10.1016/S0304-4076(98)00028-1.

Demirguc-Kunt, A., T. Beck, and P. Honohan. 2008. "Finance for All. Policies and Pitfalls in Expanding Access." A World Bank Policy Research Report.

Diagne, A., M. Zeller, and M. Sharma. 2000. 'Empirical Measurements of Households' Access to Credit and Credit Constraints in Developing Countries: Methodological Issues and Evidence." IFPRI, FCND Discussion Paper No. 90. IFPRI.

Djankov, S., C. McLiesh, and A. Shleifer. 2007. "Private Credit in 129 Countries" Journal of Financial Economics 84 (2): 299-329. https://doi.org/10.1016/j.jfineco.2006.03.004..

Ezeoha, A., and F. Botha. 2012. "Firm Age, Collateral Value and Access to Debt Financing in an Emerging Economy: Evidence from South Africa." South African Journal of Economic and Management Sciences 15: 55-71. https://doi.org/10.4102/sajems.v15i1.138.

Erel, I. 2011. "The Effect of Bank Mergers on Loan Prices: Evidence from the United States." Review of Financial Studies 24 (4): 1068-101. https://doi.org/10.1093/rfs/hhp034.

Fischer, K. H. 2000. “Acquisition of Information in Loan Markets and Bank Market Power: An Empirical Investigation.” Mimeo Johann Wolfgang Goethe University Frankfurt. https://doi.org/10.2139/ssrn.240921.

Fosu, S. 2013. "Banking Competition in Africa; Sub regional Comparative Studies." Discussion Papers in Economics 13/12. Division of Economics, School of Business, University of Leicester.

Gaertna, M., and S. Sanya. 2012. "Assessing Bank Competition within the East African Community.” IMF Working Paper no. 12.32.

González, V. M., and F. González. 2008. "Influence of Bank Concentration and Institutions on Capital Structure: New International Evidence." Journal of Corporate Finance 14 (4): 363-375. https://doi.org/10.1016/j.jcorpfin.2008.03.010. 


\section{Moyo, Sibindi}

Global Financial Development database (2016-2019), World Bank.

http://databank.worldbank.org/data/reports.aspx?source=Global-Financial-Development.

Hay, D. A., and G. S. Liu. 1997. The Efficiency of Firms: What Difference Does Competition Make? The Economic Journal 10: 597-617. https://doi.org/10.1111/j.14680297.1997.tb00029.x.

Hauner, D., and S. H. Peiris. 2008. "Banking Efficiency and Competition in Low Income Countries: The Case of Uganda." Applied Economics 40 (21):2703-2720. https://doi.org/10.1080/00036840600972456.

Houston J. F., C. Lin., P. Lin, and Y. Ma. 2010. "Creditor Rights, Information Sharing, and Bank Risk Taking” Journal of Financial Economics 96 (3): 485-512. https://doi.org/10.1016/j.jfineco.2010.02.008.

Igan, D., A. Mirzaei, and T. Moore. 2018. "How do Regulations of Entry and Credit Access Relate to Industry Competition? International Evidence." IMF Working paper WP18/84. https://doi.org/10.5089/9781484350997.001.

ILO. 2018. "Women and Men in the Informal Economy: A Statistical Picture." Geneva, Switzerland.

Kouki, I., and A. Al-Nasser. 2014. "The Implication of Banking Competition: Evidence from African Countries." Research in International Business and Finance 39: 878-895. https://doi.org/10.1016/j.ribaf.2014.09.009.

Lipczynski, J., J. O. Wilson, and J. Goddard. 2017. "Industrial Organisation, Competition, Strategy and Policy," 5th edition. United Kingdom: Pearson Publishers.

Love, I., and N. Mylenko. 2005. "Credit Reporting and Financing Constraints." Credit Technology 50: 7-33.

Love, I., and M. S. M. Peria. 2014. "How Bank Competition Affects Firms' Access to Finance." The World Bank Economic Review 29 (3): 413-448. https://doi.org/10.1093/wber/lhu003.

Leon, F. 2014. "Does Bank Competition Alleviate Credit Constraints in Developing Countries?" Journal of Banking and Finance 57: 130-142. https://doi.org/10.1016/j.jbankfin.2015.04.005.

Medina, L., A. W. Jonelis, and M. Cangul. 2017. "The Informal Economy in Sub Saharan Africa: Size and Determinants." IMF Working Papers 17/156. https://doi.org/10.5089/9781484305942.001.

Mengistu, A., and H. Perez-Saiz. 2018: "Financial Inclusion and Bank Competition in SubSaharan Africa." IMF Working Paper WP/18/256. https://doi.org/10.5089/9781484386163.001. 


\section{Moyo, Sibindi}

Moyo, B. 2018. "An Analysis of Competition, Efficiency and Soundness in the South African Banking Sector.” ERSA Working paper 747. https://doi.org/10.4102/sajems.v21i1.2291.

Moyo, J., B. Nandwa, J. Oduor, and A. Simpasa. 2014. "Financial Sector Reforms, Competition and Banking System Stability in Sub-Saharan Africa." Paper presented at the joint RES-SPR Conference on Macroeconomic Challenges Facing Low-Income Countries.

Narain, S. 2009. “Gender and Access to Finance.” World Bank Research Paper.

Ncube, M. 2013. “Recognising Africa's Informal sector.” African Development Bank. Accessed January 2018. https://www.afdb.org/en/blogs/afdb-championing-inclusivegrowth-across-africa/post/recognizing-africas-informal-sector-11645/MPRA Paper No 73598.

Owen, A. L., and J. Pereira. 2016. "Bank Concentration, Competition and Financial Inclusion." https://doi.org/10.2139/ssrn.2836521.

Padilla, A. J., and M. Pagano. 2000. "Sharing Default Information as a Borrower Discipline Device.” European Economic Review 44 (10): 1951-80. https://doi.org/10.1016/S00142921(00)00055-6.

Petersen, M., and R. Rajan. 1995. "The Effect of Credit Market Competition on Lending Relationships." Quarterly Journal of Economics 110: 407-443. https://doi.org/10.2307/2118445.

Popov, A., and G. Udell. 2012. "Cross-border Banking, Credit Access, and the Financial Crisis.” Journal of International Economics 87: 147-161. https://doi.org/10.1016/j.jinteco.2012.01.008.

Prata, P. S., and E. Quintin. 2006. "The Informal Sector in Developing Countries. Output Assets and Employment." UNU-WIDER Research paper No 2006/130.

Rice, T., and P. E. Strahan. 2008. "Does Credit Supply Affect Small Firm Finance?” Finance and Economics Discussion Working Paper Series 2008-54. https://doi.org/10.17016/FEDS.2008.54.

Richardson, P., H. Rhona, and G. Finnegan. 2004. "The Challenges of Growing Small Businesses: Insights from Women Entrepreneurs in Africa." .ILO Geneva, SEED Working Paper No. 47.

Rosenthal, R. 1980. "A Model in which an Increase in the Number of Sellers Leads to a Higher Price.” Econometrica 48 (6): 1575-1579. https://doi.org/10.2307/1912828.

Ryan, R. M., C. M. O’Toole, and F. McCann. 2014. "Does Bank Market Power Affect SME Financing Constraints?" Journal of Banking and Finance 49: 495-505. https://doi.org/10.1016/j.jbankfin.2013.12.024. 


\section{Moyo, Sibindi}

Schaeck, K., M. Cihak, and S. Wolfe. 2009. "Are Competitive Banking Systems more stable?" Journal of Money Credit and Banking 41 (4): 711-734. https://doi.org/10.1111/j.15384616.2009.00228.x.

Simpasa, A. M. 2013. "Competition and Market Structure in the Zambian Banking Sector." African Development Bank Working paper series 168. https://doi.org/10.1111/j.14678268.2010.00274.x.

Stiglitz, J. 1989. "Imperfect Information in The Product Market." In Handbook of Industrial Organization, edited by R. Schmalensee and R. Willig, volume. I. Amsterdam: Elsevier Science Publishers. https://doi.org/10.1016/S1573-448X(89)01016-2.

Tacneng, R. 2014. "Local Banking Market Structure and SME Financing Obstacles: Evidence from the Philippines." LAPE Working Paper.

Tchamyou, V. S. 2018. "Education, Lifelong Learning, Inequality and Financial Access: Evidence from African countries.” AGDI Working paper WP/18/003.

Vives, X. 2001. "Competition in the Changing World of Banking." Oxford Review of Economic Policy 17 (4): 535-45. https://doi.org/10.1093/oxrep/17.4.535.

Worldwide Governance Indicators. 2018. Washington DC, World Bank.

http://databank.worldbank.org/data/reports.aspx?source=worldwide-governance-indicators.

World Development Indicators 2018. Washington DC, World Bank. http://databank.worldbank.org/data/reports.aspx?source=world-development-indicators.

WIEGO. 2012. Informal Economy Statistics. http://www.wiego.org/informaleconomy/statistical-picture.

World Bank. 2011. Policies to Reduce Informal Employment: An International Survey. Technical Note for the Government of Ukraine.

World Bank Enterprise Surveys. 2020. Washington DC, World Bank. https://www.enterprisesurveys.org/portal/index.aspx\#/library?dataset=Enterprise\%20Surve y.

World Economic Outlook Database. 2020. Washington DC, International Monetary Fund. https://www.imf.org/en/Publications/WEO/weo-database/2020/April, Chicago, IL.

Zarutskie, R. 2006. "Evidence on the Effects of Bank Competition on Firm Borrowing and Investment." Journal of Financial Economics 81: 503-537. https://doi.org/10.1016/j.jfineco.2005.07.008. 
Moyo, Sibindi

\section{Appendix}

Table 7: Pearson correlation matrix using competition indicators

\begin{tabular}{|c|c|c|c|c|c|c|c|}
\hline & $\begin{array}{l}\text { Lerne } \\
\mathbf{r}\end{array}$ & $\begin{array}{l}\text { Boon } \\
\text { e }\end{array}$ & $\begin{array}{l}\text { Concentrati } \\
\text { on } 5\end{array}$ & $\begin{array}{l}\text { Bank } \\
\text { concentrati } \\
\text { on }\end{array}$ & $\begin{array}{l}\text { H } \\
\text { statisti } \\
\text { c }\end{array}$ & $\begin{array}{l}\text { Broad } \\
\text { Money/GD } \\
\text { P } \\
\end{array}$ & $\begin{array}{l}\text { Bank } \\
\text { branche } \\
\text { s }\end{array}$ \\
\hline Lerner & $\begin{array}{l}1.000 \\
0\end{array}$ & & & & & & \\
\hline Boone & $\begin{array}{l}- \\
0.550 \\
3\end{array}$ & $\begin{array}{l}1.000 \\
0\end{array}$ & & & & & \\
\hline $\begin{array}{l}\text { Concentrati } \\
\text { on } 5\end{array}$ & $\begin{array}{l}- \\
0.337 \\
5\end{array}$ & $\begin{array}{l}0.306 \\
2\end{array}$ & 1.0000 & & & & \\
\hline $\begin{array}{l}\text { Bank } \\
\text { concentratio } \\
\text { n }\end{array}$ & $\begin{array}{l}- \\
0.231 \\
2\end{array}$ & $\begin{array}{l}0.115 \\
0\end{array}$ & 0.9286 & 1.0000 & & & \\
\hline H statistic & $\begin{array}{l}0.004 \\
2 \\
\end{array}$ & $\begin{array}{l}0.171 \\
2\end{array}$ & 0.2580 & 0.4655 & 1.0000 & & \\
\hline $\begin{array}{l}\text { Broad } \\
\text { Money/GDP }\end{array}$ & $\begin{array}{l}0.095 \\
9\end{array}$ & $\begin{array}{l} \\
0.311 \\
2\end{array}$ & -0.1705 & 0.0265 & 0.0933 & 1.0000 & \\
\hline $\begin{array}{l}\text { Bank } \\
\text { branches }\end{array}$ & $\begin{array}{l}0.121 \\
0\end{array}$ & $\begin{array}{l}-\bar{l} \\
0.385 \\
6\end{array}$ & -0.2466 & 0.2000 & 0.1029 & 0.6772 & 1.0000 \\
\hline
\end{tabular}

Source: Author's calculation based on World Bank enterprise data, World Development Indicators and Global Development Finance data 
Moyo, Sibindi

Table 8: Firm-level characteristics

\begin{tabular}{|c|c|c|c|c|c|c|c|c|c|c|c|c|c|c|}
\hline & \multirow{2}{*}{$\begin{array}{l}\text { Public } \\
\text { Credit } \\
\text { Regist } \\
\text { ry (\%) }\end{array}$} & \multirow{2}{*}{$\begin{array}{l}\text { Privat } \\
\text { e } \\
\text { Credi } \\
\text { t } \\
\text { Burea } \\
\text { u (\%) }\end{array}$} & \multicolumn{4}{|c|}{ FIRM AGE (years) } & \multicolumn{5}{|c|}{ FIRM SIZE** } & \multicolumn{3}{|c|}{$\begin{array}{l}\text { OWNER } \\
\text { EXPERIENCE IN } \\
\text { SECTOR (years) } \\
\end{array}$} \\
\hline & & & $\begin{array}{l}\text { Mea } \\
\text { n }\end{array}$ & $\begin{array}{l}\text { Mi } \\
\text { n }\end{array}$ & $\begin{array}{l}\text { Ma } \\
\mathbf{x}\end{array}$ & $\begin{array}{l}\text { Std } \\
\text { de } \\
v\end{array}$ & $\begin{array}{l}\text { Mea } \\
\text { n }\end{array}$ & $\begin{array}{l}\text { Mi } \\
\text { n }\end{array}$ & $\begin{array}{l}\text { Ma } \\
\mathbf{x}\end{array}$ & $\begin{array}{l}\text { St } \\
\text { d } \\
\text { de } \\
\text { v }\end{array}$ & $\begin{array}{l}\text { Mea } \\
\text { n }\end{array}$ & $\begin{array}{l}\text { Mi } \\
\mathbf{n}\end{array}$ & $\begin{array}{l}\text { Ma } \\
\mathbf{x}\end{array}$ & $\begin{array}{l}\text { Std } \\
\text { de } \\
v\end{array}$ \\
\hline $\begin{array}{l}\text { Angola } \\
(2010)\end{array}$ & 2.5 & 0.0 & 6.0 & 0 & 37 & 5.1 & 10.5 & 1.8 & $\begin{array}{l}16 . \\
5 \\
\end{array}$ & 2.7 & 7.8 & 1 & 25 & 4.1 \\
\hline $\begin{array}{l}\text { Botswana } \\
(2010)\end{array}$ & 0.0 & 51.9 & 5.9 & 0 & 53 & 5.9 & 8.4 & 5.2 & $\begin{array}{l}11 . \\
0\end{array}$ & 1.3 & 7.6 & 0 & 50 & 7.1 \\
\hline $\begin{array}{l}\text { Burkina } \\
\text { Faso } \\
(2009) \\
\end{array}$ & 1.9 & 0.0 & 8.9 & 0 & 34 & 6.4 & 8.7 & 5.3 & $\begin{array}{l}12 . \\
5\end{array}$ & 1.2 & 10.8 & 1 & 50 & 7.6 \\
\hline $\begin{array}{l}\text { Cabo } \\
\text { Verde } \\
(2009) \\
\end{array}$ & 21.8 & 0.0 & 9.2 & 0 & 50 & 7.7 & 8.9 & 5.0 & $\begin{array}{l}14 . \\
4\end{array}$ & 1.9 & 11.9 & 1 & 50 & 9.1 \\
\hline $\begin{array}{l}\text { Cameroon } \\
(2009)\end{array}$ & 4.9 & 0.0 & 7.3 & 0 & 33 & 6.5 & 8.5 & 5.5 & $\begin{array}{l}11 . \\
2\end{array}$ & 1.2 & 9.5 & 1 & 36 & 7.3 \\
\hline $\begin{array}{l}\text { DRC } \\
(2013) \\
\end{array}$ & 0.0 & 0.0 & 7.2 & 0 & 38 & 6.7 & 13.8 & $\begin{array}{l}10 . \\
4\end{array}$ & $\begin{array}{l}18 . \\
9\end{array}$ & 1.3 & 9.5 & 1 & 42 & 7.8 \\
\hline $\begin{array}{l}\text { Ghana } \\
(2013)\end{array}$ & 0.0 & 5.7 & 8.6 & 0 & 131 & 9.3 & 7.9 & 4.5 & $\begin{array}{l}12 . \\
4\end{array}$ & 1.2 & 9.5 & 0 & 50 & 8.5 \\
\hline $\begin{array}{l}\text { Kenya } \\
(2013)\end{array}$ & 0.0 & 4.9 & 6.5 & 0 & 43 & 6.4 & 7.4 & 1.9 & $\begin{array}{l}11 . \\
9\end{array}$ & 1.2 & 8.1 & 0 & 50 & 7.2 \\
\hline $\begin{array}{l}\text { Madagasc } \\
\text { ar (2009) }\end{array}$ & 0.1 & 0.0 & 7.3 & 1 & 50 & 8.3 & 6.9 & 4.1 & $\begin{array}{l}10 . \\
8\end{array}$ & 1.3 & 7.3 & 1 & 39 & 8.8 \\
\hline $\begin{array}{l}\text { Mali } \\
(2010)\end{array}$ & 4.0 & 0.0 & 9.4 & 0 & 47 & 8.3 & 8.4 & 5.1 & $\begin{array}{l}11 . \\
9\end{array}$ & 1.3 & 11.7 & 1 & 50 & 8.6 \\
\hline $\begin{array}{l}\text { Mauritius } \\
(\mathbf{2 0 0 9})\end{array}$ & 20.6 & 0.0 & 15.3 & 1 & 86 & $\begin{array}{l}12 . \\
9\end{array}$ & 8.3 & 1.2 & $\begin{array}{l}11 . \\
6\end{array}$ & 1.3 & 18.3 & 2 & 50 & $\begin{array}{l}11 . \\
1 \\
\end{array}$ \\
\hline $\begin{array}{l}\text { Mozambiq } \\
\text { ue (2018) } \\
\end{array}$ & 7.3 & 0.0 & 5.2 & 0 & 38 & 6.5 & 0.9 & $\begin{array}{l}0.0 \\
7 \\
\end{array}$ & 3.0 & 0.7 & 6.5 & 1 & 47 & 7.3 \\
\hline $\begin{array}{l}\text { Rwanda } \\
\text { (2011) }\end{array}$ & 0.7 & 0.0 & 5.6 & 0 & 40 & 6.2 & 6.7 & $\begin{array}{l}- \\
0.5 \\
8\end{array}$ & $\begin{array}{l}10 . \\
5\end{array}$ & 1.8 & 7.4 & 0 & 40 & 7.2 \\
\hline $\begin{array}{l}\text { Zimbabwe } \\
(2018)\end{array}$ & 7.1 & 33.6 & 6.9 & 1 & 53 & 6.9 & 7.6 & 4.3 & $\begin{array}{l}11 . \\
0\end{array}$ & 1.3 & 7.7 & 1 & 52 & 7.8 \\
\hline
\end{tabular}

Source: Author's calculation based on World Bank enterprise data. ** Firm size is measured using firms' average monthly output multiplied by 12 , converted into US $\$$ and then natural logs. 
Moyo, Sibindi

Table 9: Summary country-level statistics

\begin{tabular}{|l|l|l|l|l|}
\hline & Mean & Min & Max & Std dev \\
\hline Lerner & 0.33 & 0.19 & 0.46 & 0.099 \\
\hline Boone & -0.034 & -0.12 & 0.24 & 0.11 \\
\hline Concentration 5 & 74.3 & 54.3 & 100 & 15,4 \\
\hline Bank concentration & 56.7 & 36.7 & 89.1 & 16.5 \\
\hline H statistic & 0.39 & 0.06 & 0.76 & 0.17 \\
\hline Broad Money/GDP & 33.1 & 12.5 & 96.3 & 19.9 \\
\hline Bank branches & 5.8 & 0.64 & 28.2 & 5.4 \\
\hline Public credit registry & 5.1 & 0.00 & 21.8 & 5.5 \\
\hline Private Credit Bureau & 6.9 & 0.00 & 51.9 & 12.9 \\
\hline
\end{tabular}

Source: Author's calculation based on World Bank enterprise data 